\title{
Prevalence and Etiology of Subclinical Mastitis in Dairy Cattle
}

\author{
P. V. Tresamol*, R. L. Rathish, Aaron Jacob and M. R. Saseendranath \\ Department of Veterinary Epidemiology and Preventive Medicine, College of Veterinary and \\ Animal Sciences, Mannuthy, India \\ *Corresponding author
}

\section{A B S T R A C T}

\begin{tabular}{|l|}
\hline Key w o r d s \\
$\begin{array}{l}\text { Subclinical mastitis, } \\
\text { cattle, Prevalence, } \\
\text { Pathogens, } \\
\text { Antibiogram }\end{array}$ \\
\hline Article Info \\
$\begin{array}{l}\text { Accepted: } \\
\text { 25 May } 2021 \\
\text { Available Online: } \\
\text { 10 June } 2021\end{array}$ \\
\hline
\end{tabular}

\section{Introduction}

Bovine mastitis is a major infectious disease that affects dairy cattle throughout the world and results in substantial economic losses to dairy farmers. The disease results in partial or complete damage to udder tissue and leads to loss of productivity from affected quarter. The consequences due to reductions in milk yield, changes in milk composition, discarded milk and loss of genetic potential are serious economic losses for the farmers and the dairy industry (Godkin et al., 1990). Subclinical mastitis was found more important in India (varying from 10-50\%) than clinical mastitis (1-10\%) (Joshi and Ghokale, 2006). Antimicrobial therapy is the most common way of treating mastitis in dairy cattle. 
Indiscriminate use of antibiotics for treatment has led to development of antimicrobial resistance. Moreover the disease is caused by many bacteria and other organisms like fungi, yeasts and viruses (Kotowshi, 1988).

Subclinical mastitis not only causes reduction of milk yield and higher predisposition to clinical mastitis, but also adversely affects hygienic quality and physicochemical properties of milk (Constable et al., 2017). This form of mastitis is more important because of higher rate of prevalence than clinical form, long course, difficult to diagnose, prolonged economic loss and poor milk quality which usually goes unnoticed and leads to clinical mastitis. The present study was conducted to assess the prevalence of subclinical mastitis among lactating dairy cows in organized farms and to investigate the etiology of the condition.

\section{Materials and Methods}

A total of 139 lactating cows belonging to three organized farms in Thrissur district were screened for subclinical mastitis using three cow side tests such as California mastitis test (CMT), electrical conductivity (EC) and somatic cell count (SCC). California mastitis Test was done at cow side, by mixing an equal volume of milk with CMT reagent in clean wells of a plastic test paddle. The paddle was rotated gently, to observe any colour changes or formation of a viscous gel. Scores were given within the range 0 to 3 , with ' 0 ' for no reaction, ' 1 ' for a weak positive, ' 2 ' for a distinct positive, and ' 3 ' for a strong positive. Electrical conductivity of the quarter milk samples were tested using Milk checker. It is a handy type instrument to measure the electrical conductivity of milk to detect mastitis. The milk was directly taken from the quarters and results were displayed for all quarters of the udder at the same time. The results of the difference between quarters of the udder will also be displayed. Somatic cell counts were performed using the instrument, De Laval Direct Cell Counter (DCC). It is a new device that is designed to be used on farms for rapid enumeration of somatic cells. Small cassettes designed to be used on farms for rapid enumeration of somatic cells. The cassettes are filled with approximately $1 \mu 1$ of fresh milk, stained automatically in the cassette and inserted into a small battery operated optical cell counter.

Milk samples from the cows with subclinical mastitis were collected aseptically in sterile vials and subjected to culture and sensitivity test. A total of 117 milk samples were collected from positive cases and primary isolation of microorganisms was done in Brain Heart Infusion agar. The isolates obtained were identified using the colony morphology, microscopical examination of Gram's stained smears of the culture and by using various biochemical tests as per Barrow and Feltham (2004). All isolates were subjected to antibiogram studies in Mueller- Hinton agar plates and were incubated at $37^{\circ} \mathrm{C}$ for 24 hours. Later these plates were examined for the development of zone of inhibition around discs and the diameter of the zone of inhibition measured in millimeter were compared with the standard chart provided by the manufacturer.

\section{Results and Discussion}

A total of 547 quarter milk samples from 139 lactating animals were screened for subclinical mastitis using California mastitis test. Out of 547, 175 were strongly positive (score 3), 67 samples were distinct positive (score 2), 62 samples were weakly positive (score 1) and 243 were negative(score 0 ). Percent positivity of quarter samples comes to 55.57 per cent. Among 139 animals 112 animals were with subclinical mastitis positive quarters, which come to 80.5 per cent. Among 547 quarters 
170 were having electrical conductivity of more than 6 millisiemens ( 31.08 per cent) and 377 samples were having less than 6 millisiemens (68.92 percent). Among 139 animals 81 were positive (58.27 per cent) and 58 were negative (41.73 percent) for subclinical mastitis based on differential electrical conductivity. Among pooled milk samples from 139 animals only 22 animals were having a SCC of less than 2,50,000 cells/ml (15.83 per cent) and rest of the animals (84.17) were having a somatic cell count ranging from $2,50,000$ to $60,00,000$ cells $/ \mathrm{ml}$.

The California Mastitis Test is a simple, inexpensive, rapid screening test for mastitis. The test is based upon the amount of cellular nuclear protein present in the milk sample and reflects the SCC level quite accurately and is a reliable indicator of the severity of infection. The test is appropriate for cow-side evaluation of udder health. Mastitic milk has a higher electrical conductivity than normal milk and is one of the earliest manifestations associated with new infections. The greatest problem associated with this new technology is the variation in sensitivity and specificity of electrical conductivity between herds.

A positive indication of increased electrical conductivity in a specific animal is an indication for further evaluation of that animal and not generally a signal for immediate treatment. The use of differential EC has been shown to improve the ability of EC to detect mastitis (Neilen et al., 1992). The SCC from individual cows can span a very wide range of values. Chances of isolating a major pathogen increase when quarter SCC's are above 200,000cells $/ \mathrm{ml}$. Somatic Cell Counts of composite quarters have shown that a threshold value of approximately 250,000 cells $/ \mathrm{ml}$ is reasonable for differentiating infected from noninfected quarters. A total of 117 milk samples of subclinical mastitis were subjected to culture and sensitivity testing, of which 98 samples yielded growth of microorganisms. Out of the 98 samples 97(98.98 percent) were Gram positive and one (1.02 percent) was Gram negative. Biochemical tests for identification of the isolates revealed Staphylococcus aureus (39), coagulase negative Staphylococci (52), Streptococcus spp. (3), Micrococcus spp. (1) and Staphylococcus intermedius (2). Similar findings were also reported by Mekibib et al., (2010). Sreenivasan et al., (2013) also reported Staphylococcus spp. as the major pathogen associated with subclinical mastitis. An increase in the prevalence of subclinical mastitis due to coagulase negative staphylococci was also reported by Sharma et al., (2012). Gram negative bacilli were not isolated from this study as reported by above workers except one isolate of Pseudomonas spp. OldeRiekerink et al., (2008) reported variations in the incidence rate and type of pathogens of subclinical mastitis among different canadiandairy farms. Out of 117 milk samples of subclinical mastitis subjected to culture, no bacterial growth was obtained in 19 samples. This may be due to the low concentration of bacteria or to the fastidious nutritional and growth requirements as suggested by Taponen et al.,(2009).Recent studies by Kuehn et al., (2013) also suggested that mastitis may be associated not only with the mastitis pathogens but also with an imbalance of the milk microbiota.

Antibiogram studies of isolates revealed enrofloxacin as the most sensitive (85.71 percent) followed by cefaperozone ( 84.13 per cent), chloramphenicol (80.95 per cent), tetracycline (74.6 per cent), ceftriaxonetazobactam (71.43 per cent), ceftizoxime (66.67 per cent) and co-trimoxazole (66.67 per cent). Jeykumar et al., (2013) also reported enrofloxacin as the most sensitive antibiotic in bovine mastitis in Tamil Nadu. Findings contradictory to this observation were also 
reported in other regions (Paul et al., 2000; Sudhakar et al., 2009).

The findings of the present study reveal a higher prevalence of subclinical mastitis among dairy herds. It is very important to identify the predominant mastitis-causing pathogens in order to develop successful control programs for mastitis. The early diagnosis and prevention of subclinical mastitis must be a priority for each dairy holder for acquisition of good quality milk and the prevention of economical losses.

\section{Acknowledgement}

The authors wish to thank the Dean, College of Veterinary and Animal Sciences, Mannuthy for providing the facilities and Director of Animal Husbandry, Kerala, for the financial support.

\section{References}

Barrow, G. I and Feltham R. K. A.2004. Cowan and Steel's Manual for Identification of Medical Bacteria. Third edition.Cambridge Books.

Constable, P. D., Hinchcliff, K. W., Done, S. H. and Grunberg, W. 2017. Diseases of mammary gland, In: Veterinary Medicine, 11th Edn. Elseveir Ltd. St. Louis, Missouri, pp1904- 2001

Godkin, A., Leslie, K. and Martin, W.1990. Mastitis in bulk tank milk culture in Ontario.Highlights, 13(2):13-16

Jeykumar, M., Vinodkumar, G., Bashir, B. P. and Krovvidi, S. 2013 Antibiogram of mastitis pathogens in the milk of crossbred cows in Namakkal district, Tamil Nadu, Vet. World 6:354-356

Joshi, S. and Gokhale, S. 2006. Status of mastitis as an emerging disease in improved and periurban dairy farms in India. Annals of the New York Academy of Sciences, 1081: 74-83
Kotowski, K.1988. Bacterial flora isolated from cases of bovine mastitis and its antibiotic sensitivity. MedycycaVeteynaryja, 43 (5): 278-280 Kuehn J. S., Gorden P. J., Munro D., Rong R., Dong Q., Plummer P. J., et al., 2013. Bacterial community profiling of milk samples as a means to understand culture-negative bovine clinical mastitis. PLoS One 8:e61959. 10.1371/journal.pone.0061959

Mekibib, B., Furgasa, M., Abunna, F., Megersa. B. and Regassa, A. 2010. Bovine Mastitis: Prevalence, Risk Factors and Major Pathogens in Dairy Farms of Holeta Town, Central Ethiopia. Vet World. 3(9): 397-403

Neilen M., Deluyker H, Schukken Y H, Brand A. 1992. Electrical conductivity of milk: measurement, modifiers, and meta analysis of mastitis detection performance. J. Dairy Sci. 75:606-614

OldeRiekerink R. G., Barkema H. W., Kelton D. F. and Scholl D. T. 2008. Incidence rate of clinical mastitis on Canadian dairy farms. J. Dairy Sci. 91 13661377.

Paul, W. M., Parthiban, M., Menaka, R. and Nainar A. M. 2000. The occurrence and antibiogram of bacterial isolates from milk samples of bovine subclinical mastitis. Indian $J$. Anim.Hlth, 39:79-81

Seegers, H., Fourichon, C. and Beaudeau, F. 2003. Production effects related to mastitis and mastitis economics in dairy cattle herds. Vet Res. 34:475-491.

Sharma, N., Rho, G. J., Hong, Y. H., Kang, T. Y., Lee, H. K., Hur, T. Y. and Jeong, D. K. 2012. Bovine Mastitis: An Asian Perspective. Asian J. Anim. Vet. Adv. 7: 454-476.

Srinivasan, P., Jagadeswaran, D., Manoharan R., Giri, T., Balasubramaniam, A. and Balachandran,P.2013.Prevalence and Etiology of Subclinical Mastitis among 
Buffaloes (Bubalus bubalus) in Namakkal, India. Pakistan J. Biol. Sci.16: 1776-1780.

Sudhakar, P. A., Narendra, V. K., Vikas, M. S. and Mangesh 2009 Prevalence and current antibiogram trend of mastatic agents in Udgir and its vicinity, Maharashtra state, India. Int. J. Dairy
Sci., 4:117-122.

Taponen S., Salmikivi L., Simojoki H., Koskinen M. T., Pyorala S. 2009. Real-time polymerase chain reactionbased identification of bacteria in milk samples from bovine clinical mastitis with no growth in conventional culturing. J. Dairy Sci. 92: 2610-2617.

\section{How to cite this article:}

Tresamol, P. V., R. L. Rathish, Aaron Jacob and Saseendranath, M. R. 2021. Prevalence and Etiology of Subclinical Mastitis in Dairy Cattle. Int.J.Curr.Microbiol.App.Sci. 10(06): 666-670. doi: https://doi.org/10.20546/ijcmas.2021.1006.073 